\title{
Recent advances in understanding hematopoiesis in Fanconi
}

\section{Anemia [version 1; peer review: 4 approved]}

\author{
Grover Bagby (iD)
}

Departments of Medicine and Molecular and Medical Genetics, Division of Hematology and Medical Oncology, Knight Cancer Institute, Oregon Health \& Science University, Portland, Oregon, USA

V1 First published: 24 Jan 2018, 7(F1000 Faculty Rev):105

https://doi.org/10.12688/f1000research.13213.1

Latest published: 24 Jan 2018, 7(F1000 Faculty Rev):105

https://doi.org/10.12688/f1000research.13213.1

\section{Abstract}

Fanconi anemia is an inherited disease characterized by genomic instability, hypersensitivity to DNA cross-linking agents, bone marrow failure, short stature, skeletal abnormalities, and a high relative risk of myeloid leukemia and epithelial malignancies. The 21 Fanconi anemia genes encode proteins involved in multiple nuclear biochemical pathways that effect DNA interstrand crosslink repair. In the past, bone marrow failure was attributed solely to the failure of stem cells to repair DNA. Recently, non-canonical functions of many of the Fanconi anemia proteins have been described, including modulating responses to oxidative stress, viral infection, and inflammation as well as facilitating mitophagic responses and enhancing signals that promote stem cell function and survival. Some of these functions take place in non-nuclear sites and do not depend on the DNA damage response functions of the proteins. Dysfunctions of the canonical and non-canonical pathways that drive stem cell exhaustion and neoplastic clonal selection are reviewed, and the potential therapeutic importance of fully investigating the scope and interdependences of the canonical and non-canonical pathways is emphasized.

\section{Keywords}

Fanconi anemia, hematopoiesis, stem cells, DNA repair, oxidative stress, mitophagy, autophagy, virophagy, inflammation, interferon, tumor necrosis factor, TGF, leukemogenesis, bone marrow failure, aplastic anemia, gene therapy, bone marrow transplantation

\section{Open Peer Review}

$\begin{array}{cccc}\text { Approval Status } & \\ 1 & 2 & 3 & 4\end{array}$

version 1

24 Jan 2018

Faculty Reviews are review articles written by the prestigious Members of Faculty Opinions. The articles are commissioned and peer reviewed before publication to ensure that the final, published version is comprehensive and accessible. The reviewers who approved the final version are listed with their names and affiliations.

1. Qishen Pang, Cincinnati Children's Hospital Medical Center, Cincinnati, USA

2. Andrew Deans, St. Vincent's Institute of Medical Research, Fitzroy, Australia

3. Jakub Tolar, University of Minnesota,

Minneapolis, USA

4. Alex Lyakhovich, Vall d'Hebron Research Institute, Barcelona, Spain

Any comments on the article can be found at the end of the article. 
Corresponding author: Grover Bagby (grover@ohsu.edu)

Author roles: Bagby G: Conceptualization, Project Administration, Writing - Original Draft Preparation, Writing - Review \& Editing Competing interests: No competing interests were disclosed.

Grant information: This work was supported by National Institutes of Health Grants (P01 HL048546, R01 CA 1138237, P30 CA69533) and the U.S. Department of Veterans Affairs (Merit Review).

The funders had no role in study design, data collection and analysis, decision to publish, or preparation of the manuscript.

Copyright: @ 2018 Bagby G. This is an open access article distributed under the terms of the Creative Commons Attribution License, which permits unrestricted use, distribution, and reproduction in any medium, provided the original work is properly cited.

How to cite this article: Bagby G. Recent advances in understanding hematopoiesis in Fanconi Anemia [version 1; peer review: 4 approved] F1000Research 2018, 7(F1000 Faculty Rev):105 https://doi.org/10.12688/f1000research.13213.1

First published: 24 Jan 2018, 7(F1000 Faculty Rev):105 https://doi.org/10.12688/f1000research.13213.1 


\section{Introduction}

Fanconi anemia (FA) is a rare inherited syndrome characterized by progressive bone marrow failure (BMF) and a high relative risk of hematopoietic and epithelial malignancies in children who sometimes have characteristic developmental abnormalities, including short stature and radial ray defects. Since the first clinical report of this disease 90 years ago ${ }^{1}$, important clinical advances have included the development of the gold-standard diagnostic test (chromosomal breakage responses when lymphocytes or fibroblasts are exposed to low doses of either mitomycin $\mathrm{C}$ or diepoxybutane $)^{2-4}$ and major improvements in the application of stem cell transplantation to cure the hematopoietic defect in children with $\mathrm{FA}^{5-13}$. Not all patients have a suitable donor, and successful transplants are not infrequently associated with the subsequent development of solid tumors and other unique 'late effects ${ }^{14-17}$, so less toxic forms of therapy are clearly desirable. Their development does, however, require a more complete understanding of molecular pathogenesis than any of us has today. The first hurdle cleared on this point of pathogenesis was the identification of the commonly mutated genes. Since the cloning of the first gene (FANCC) in $1992^{18,19}, 20$ other genes have been identified (Table 1 ) and others may soon be confirmed ${ }^{20}$. The field of DNA damage repair has advanced substantially as a result of this work, and novel factors that contribute to BMF in FA have emerged. Although this is a rare disorder, it is increasingly serving as a pathophysiological paradigm for more common acquired hematopoietic disorders in patients without $\mathrm{FA}^{21-24}$.

\section{Genetics}

FA is an autosomal recessive disorder (except those rare cases associated with mutations of FANCB located on chromosome $\mathrm{X}^{25}$ and autosomal dominant mutations of $\mathrm{FANCR}^{26}$ ). For a DNA sequence to be considered an FA gene, an inactivating mutation must be associated with classic chromosomal breakage in response to ex vivo challenge with cross-linking agents (mitomycin $\mathrm{C}$ or diepoxybutane) in at least one patient and complementation with the wildtype version of the mutant alleles must correct the aberrant chromosomal breakage response. Most patients will have signs of BMF and a high likelihood of developing epithelial malignancies early in life, but few patients (for example, those with FANCM mutations) develop malignancies without first showing clinical signs of marrow failure ${ }^{27}$. Whether the hematopoietic stem cells (HSCs) of FANCM patients are truly 'fit' is still in question because HSCs in the FANCM-deficient murine model have not been stringently tested in vivo (for example, using competitive repopulation analysis or exposure to inflammatory stressors) ${ }^{28}$.

Table 1. Fanconi anemia genes.

\begin{tabular}{|l|l|l|l|}
\hline Gene & Synonyms & Chromosome & References \\
\hline FANCA & & $16 q 24.3$ & 29 \\
\hline FANCC & $9 q 22.32$ & 18,19 \\
\hline FANCG & XRCC9 & $9 \mathrm{p} 13.3$ & 30 \\
\hline FANCE & $6 p 21.31$ & 31 \\
\hline FANCF & & $11 p 14.3$ & 32 \\
\hline FANCL & & $2 \mathrm{p} 16.1$ & 33 \\
\hline FANCB & FAAP95 & Xp22.2 & 25 \\
\hline FANCM & & $14 q 21.1$ & 27,34 \\
\hline FANCI & & $15 q 26.1$ & 35,36 \\
\hline FANCD2 & & $3 p 25.3$ & 37 \\
\hline FANCD1 & BRCA2 & $13 q 13.1$ & 38 \\
\hline FANCJ & BRIP1 & $17 q 23.2$ & 39,40 \\
\hline FANCN & PALB2 & $16 p 12.2$ & 41 \\
\hline FANCO & RAD51C & $17 q 22$ & 42 \\
\hline FANCP & SLX4 & $16 p 13.3$ & 43,44 \\
\hline FANCQ & ERCC4 and XPF & $16 p 13.12$ & 45 \\
\hline FANCR & RAD51 & $15 q 15.1$ & 46 \\
\hline FANCS & BRCA1 & $17 q 21.31$ & 47,48 \\
\hline FANCT & UBE2T & $1 q 31.3$ & 49 \\
\hline FANCU & XRCC2 & $7 q 36.1$ & 50,51 \\
\hline FANCV & REV7 and MAD2L2 & $1 \mathrm{p} 36.22$ & 52 \\
\hline & & & \\
\hline
\end{tabular}




\section{Stabilizing the genome: the canonical functions of Fanconi anemia proteins}

Every FA gene encodes a protein that functions unambiguously to facilitate repair of cross-linked DNA. In response to interstrand crosslinks (ICLs), a core complex of eight proteins (FANCA, -B, $-\mathrm{C},-\mathrm{E},-\mathrm{F},-\mathrm{G},-\mathrm{L}$, and $-\mathrm{M})$ is required $\mathrm{d}^{53,54}$ for monoubiquitinylation

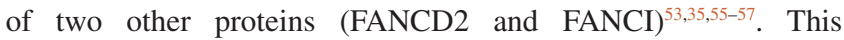
post-translational modification is required for the 'downstream' activation of other proteins that unhook ICLs (FANCP and FANCQ) and facilitate homologous recombination (FANCD1, $-\mathrm{J},-\mathrm{N},-\mathrm{O},-\mathrm{R},-\mathrm{S}$, and $-\mathrm{U})^{58}$. Other nuclear functions of FA proteins in mitosis prevent aneuploidy and aberrant centrosome accumulation ${ }^{59-61}$. This review focuses on molecular pathogenesis in FA hematopoietic tissues and addresses the question of whether the canonical functions of the FA proteins account for all of the phenotypic features characteristic of this disease.

\section{Hematopoietic defects and the prospects of gene therapy}

Although clinical marrow failure progresses over time in the lives of patients with FA, it is clear that HSCs are defective early in development. That functionally corrective somatic mutations in a single human HSC prenatally are capable of completely replacing the hematopoietic tissues in twins by the time of birth ${ }^{62}$ is conclusive proof that the repopulating capacity and overall fitness of the mutant HSCs are unambiguously reduced during development and can be overtaken by even one HSC in which the mutation has been corrected. This conclusion has been confirmed in human

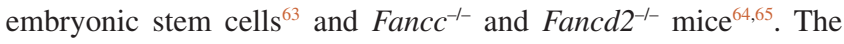
experiment of nature ${ }^{62}$ provides clear theoretical evidence that if a single corrected stem cell can so massively outperform all of the mutant ones during development, gene therapy for this disease early in life (or perhaps in utero $^{66}$ ) can be successful in the future. In fact, many preclinical and a few clinical gene therapy studies have been completed or are ongoing ${ }^{67-72}$. Although there have been no clear successes in patients yet ${ }^{73}$, the goal is within sight and entirely rational.

\section{Endogenous cross-linking factors}

Although hypersensitivity to cross-linking agents remains the sine qua non of FA diagnosis, until recently it had not been clear that cross-linking agents, apart from those that might be lurking in the external environment, played a role in the BMF so commonly found in FA. Work by Patel and colleagues has provided some important answers on this point. Having observed that alcohol dehydrogenase5 (ADH5) deficiency results in synthetic lethality when combined with FA gene suppression in the chicken DT40 cell line ${ }^{74}$, the group confirmed that loss of either $\mathrm{ADH} 5^{75}$ or aldehyde dehydrogenase$2(\mathrm{ALDH} 2)^{76}$ - enzymes that catabolically inactivate formaldehyde and acetaldehyde, respectively - markedly increases the intensity and onset of severe BMF in Fancd2-deficient mice. Given the universal intolerance of FA cells to cross-linking agents (the basis of the gold-standard diagnostic test), it is not surprising that reducing the catalysis of endogenous cross-linking agents would make the disease worse, but what is clear from these studies is that endogenous aldehydes represent major threats to FA-HSCs. Based upon these findings, it was soon discovered that Japanese FA patients with the dominant negative $A L D H 2$ allele (rs671) have accelerated $\mathrm{BMF}^{77}$. Some investigators have proposed that steadystate endogenous aldehydes themselves account for marrow failure through DNA damage-induced cell death ${ }^{78}$. This might be true but more experiments need to be done on this score because aldehydes are capable of cross-linking many more types of molecules than just DNA $^{79}$ and some cross-linked non-DNA targets stimulate two other inter-related processes known to be involved in FA pathogenesis, namely inflammation and oxidative stress $^{80-82}$. Autophagosome formation can also be directly inhibited by singlet oxygen-mediated cross-linking of p62, a scaffold protein normally involved in proper autophagosome formation and function ${ }^{83}$. Moreover, inflammatory processes can suppress the expression of ALDHs in other non-hematopoietic tissues as well as macrophages ${ }^{84-87}$. Therefore, in seeking pharmacological remedies for BMF in FA, one needs to consider not only agents that activate or otherwise enhance the function of $\mathrm{ALDHs}^{88}$ but also the basic mechanisms leading to their suppression in the face of inflammation and other stressful cues. It should also be considered that normal FA proteins might enhance the activity of ALDH isoforms directly or indirectly.

\section{Non-canonical biochemical functions contribute to molecular pathogenesis}

The coordinated interactions of FA proteins play an essential role in responding to environmental toxins, and the loss of function of any one of them destabilizes genomes. Because these proteins are so unambiguously essential in nuclear processes that protect and repair the genome, there has been a widespread tendency to simply attribute HSC dysfunction to accrued DNA damage and cell death resulting from the lost canonical functions of the proteins in DNA repair. However, recently, studies have shown that at least some of the FA proteins participate in control of signaling pathways that stress HSCs and the loss of those functions can play a role in disease progression.

Two things have become clear: (1) while all FA proteins play a role in stabilizing the genome, many of them have additional functions $^{89-100}$, some of which are independent of other FA proteins or effected outside the nuclear envelope ${ }^{90-93}$ and some are functionally independent of the DNA damage response ${ }^{102-104}$, and (2) important endogenous factors that suppress FA HSC function are emerging and include proteins normally involved in the inflammatory response $\mathrm{e}^{91,93,94,105-108}$, pathways functionally linked to or activated by inflammation, including oxidative $\operatorname{stress}^{109-117}$, mitophagy ${ }^{102}$, and the production of endogenous aldehydes ${ }^{74-77,118}$. Some of the non-canonical functions of FA proteins are listed in Table 2. In light of these disparate functions, it is no surprise that the cellular consequences of FA mutations in HSCs would necessarily include loss of quiescence ${ }^{108,119,120}$, excessive apoptosis when challenged with inflammatory cytokines or redox stress $^{110,121,122}$, and ultimately progressive stem cell attrition in the face of inflammatory stress $^{108,123}$.

\section{Inflammation: a damaging stressor in Fanconi anemia hematopoietic cells}

Because of the known myelosuppressive role of interferon gamma $($ IFN $\gamma)$ in the pathogenesis of acquired aplastic anemia ${ }^{124-126}$, early in vitro studies on FA cells were conducted to test the idea that 
Table 2. Non-canonical functions of Fanconi anemia proteins.

\begin{tabular}{|c|c|c|}
\hline $\begin{array}{l}\text { Fanconi anemia } \\
\text { proteins }\end{array}$ & Biochemical function & Expected effects \\
\hline $\begin{array}{l}\text { FANCD2 and } \\
\text { FANCA }\end{array}$ & $\begin{array}{l}\text { In response to oxidative stress, FANCD2 and FANCA form a } \\
\text { complex with BRG1 within promoters of antioxidant genes }{ }^{128} \text {. }\end{array}$ & Enhance antioxidant defenses \\
\hline FANCD2 & $\begin{array}{l}\text { Binds to FOXO3A and reduces reactive oxygen species (ROS) } \\
\text { accumulation and enhances antioxidant gene expression }{ }^{129} \text {. }\end{array}$ & $\begin{array}{l}\text { Reduces accumulation of ROS and } \\
\text { enhances cellular resistance to oxidative } \\
\text { stress }\end{array}$ \\
\hline FANCG & $\begin{array}{l}\text { Binds to and stabilizes mitochondrial PRDX3. Loss of FANCA or } \\
\text { FANCC also destabilizes PRDX }{ }^{98} \text {. }\end{array}$ & $\begin{array}{l}\text { Enhances resistance to resistance to } \mathrm{H}_{2} \mathrm{O}_{2} \\
\text { and mitomycin } \mathrm{C}\end{array}$ \\
\hline FANCC & $\begin{array}{l}\text { Binds GSTP1 and activates its activity in response to apoptotic } \\
\text { stimuli }{ }^{110} \text {. }\end{array}$ & $\begin{array}{l}\text { Prevents apoptosis in growth factor- } \\
\text { deprived hematopoietic cells }\end{array}$ \\
\hline FANCN & Binds to KEAP199 & Enhances the oxidative stress response \\
\hline $\begin{array}{l}\text { FANCC, }-A \text {, } \\
-F,-L,-D 1,-D 2, \\
\text { and }-S\end{array}$ & $\begin{array}{l}\text { Clear damaged mitochondria (mitophagy) }{ }^{102} \text {. } \\
\text { FANCA and FANCC interact with Parkin and translocate to } \\
\text { damaged mitochondria. Knockdown of FANCC, - F, or -L leads to } \\
\text { defective selective autophagy }{ }^{101} \text {. }\end{array}$ & $\begin{array}{l}\text { Decrease mitochondrial ROS production }{ }^{136} \\
\text { Reduce activation of inflammasomes }\end{array}$ \\
\hline FANCD2 & $\begin{array}{l}\text { Localizes to mitochondria and interacts with mitochondrial protein } \\
\text { (Atad3) }^{100} \text {. }\end{array}$ & $\begin{array}{l}\text { Stabilizes mitochondria, enhances } \\
\text { cisplatin resistance, and suppresses } \\
\text { apoptosis }\end{array}$ \\
\hline FANCP & $\begin{array}{l}\text { Using different domains, FANCP interacts with XPF and ERCC1 } \\
\text { to repair interstrand crosslinks and interacts with MUS81 to resist } \\
\text { TOP1 inhibitors }{ }^{89} \text {. }\end{array}$ & $\begin{array}{l}\text { Mediates resistance to both cross-linking } \\
\text { agents and topoisomerase I inhibitors }\end{array}$ \\
\hline $\begin{array}{l}\text { FANCD2 and } \\
\text { FANCA }\end{array}$ & $\begin{array}{l}\text { Suppress transforming growth factor beta signaling in } \\
\text { hematopoietic stem and progenitor cells (HSPCs) in the ground } \\
\text { state and during inflammatory stress and enhance expression of } \\
\text { genes involved in homologous recombination }{ }^{94} \text {. }\end{array}$ & $\begin{array}{l}\text { Enhance HSPC survival and function in } \\
\text { the face of inflammation and cross-linking } \\
\text { agents }\end{array}$ \\
\hline FANCC & $\begin{array}{l}\text { Binds hsp70 and suppresses the kinase activity of PKR } \\
\text { independently of the core complex }\end{array}$ & $\begin{array}{l}\text { Enhances survival of cells exposed to } \\
\text { inflammatory cytokines }\end{array}$ \\
\hline FANCC & $\begin{array}{l}\text { Binds to and facilitates activation of STAT1 in response to } \\
\text { hematopoietic growth factors }{ }^{90,92} \text {. }\end{array}$ & $\begin{array}{l}\text { Facilitates hematopoietic growth factor } \\
\text { signaling }\end{array}$ \\
\hline $\begin{array}{l}\text { FANCC and } \\
\text { FANCA }\end{array}$ & $\begin{array}{l}\text { Suppress Toll-like receptor (TLR)-induced tumor necrosis } \\
\text { factor alpha }(T N F \alpha) \text { and interleukin } 1 \text { beta }(I L-1 \beta) \text { expression in } \\
\text { macrophages }{ }^{130-132} \text {. }\end{array}$ & $\begin{array}{l}\text { Prevent overproduction of inflammatory } \\
\text { cytokines in macrophages }\end{array}$ \\
\hline FANCC & $\begin{array}{l}\text { Complexes with CtBP1 and suppresses DKK1 (a WNT suppressor) } \\
\text { gene expression }{ }^{133} \text {. }\end{array}$ & $\begin{array}{l}\text { Facilitates WNT signaling and } \\
\text { hematopoietic stem cell self-renewal }\end{array}$ \\
\hline FANCL & Ubiquitinates beta-catenin, enhancing its nuclear function ${ }^{134}$. & Enhances pluripotency of HSPCs \\
\hline FANCP & $\begin{array}{l}\text { Suppresses accumulation of cytoplasmic DNA and the } \\
\text { consequent activation of the interferon pathway }{ }^{135} \text {. }\end{array}$ & $\begin{array}{l}\text { Suppresses cGAS-STING and reduces } \\
\text { pro-inflammatory cytokine production } \\
\text { induced by replication stress }\end{array}$ \\
\hline $\begin{array}{l}\text { FANCD2 and } \\
\text { FANCl }\end{array}$ & $\begin{array}{l}\text { Associate with the spliceosomal protein SF3B1 independently of } \\
\text { the core complex and influence SF3B1 trafficking }{ }^{97} \text {. }\end{array}$ & $\begin{array}{l}\text { Enhance stem cell function }{ }^{138} \text {, coordinate } \\
\text { DNA replication and co-transcriptional } \\
\text { processes, and likely enhance } \\
\text { erythropoiesis }\end{array}$ \\
\hline
\end{tabular}

FA cells might somehow be hypersensitive to this and other known inhibitory cytokines (for example, tumor necrosis factor [TNF]). These studies were positive ${ }^{105,106,127}$ and led to the identification of some non-canonical signaling pathways with which FA proteins were directly involved ${ }^{11,93}$. These early studies were conducted in vitro, but more recent work has unambiguously confirmed that murine
FA stem cells are uniquely vulnerable to inflammatory stresses of many different kinds ${ }^{108,123}$ and that, in one informative model, blocking the function of the inflammatory cytokine interleukin 1 beta (IL-1 $\beta$ ) (a suppressor of FA HSC proliferation in vitro) ${ }^{130}$ prevented marrow failure ${ }^{123}$. Multiple inflammatory cytokines and adhesion molecules are involved in the inflammatory response, including 
factors that can enhance and others that inhibit the replicative capacity of hematopoietic stem and progenitor cells (HSPCs), so it will be important to sort out whether the 'replicative stress' induced in the FA HSPC pool plays a role in damaging the cells or whether the suppressive and pro-apoptotic and differentiationinducing effects of inflammatory cytokines cause them to perish. But the inflammatory response and its association with oxidative stress (to which FA cells are also hypersensitive ${ }^{128,129,139-141}$ ) provide opportunities for pharmacological intervention either in the ground state or during episodes of overt inflammation.

A variety of complex indirect effects likely account for some of the inflammatory vulnerabilities of FA HSCs. For example, wild-type FANCC interacts with hsp70 to suppress activation of eukaryotic translation initiation factor 2-alpha kinase 2 (PKR) in wild-type cells exposed to IFN $\gamma$ and double-stranded RNA or IFN and TNF. The interaction involves the canonical substrate-binding domain of HSP70, and loss of the FANCC/hsp70 interaction results in hyperactivation of PKR in FA cells ${ }^{91,93,107}$. Interestingly, mutations of FANCA, FANCG, and FANCC enhance the binding interaction of FANCC and PKR and result in PKR hyperactivation as well ${ }^{142}$. The recently described differential FANCA-binding functions of HSP90 and HSP70 and the functional consequences of such differential binding on the canonical function of various FANCA mutant substrates $^{143}$ add to the complexity of the future in vivo studies now required to confirm that these effects are truly independent of induced DNA damage. Finally, that ALDH and hsp70 are induced by and collaborate to control certain viral infections ${ }^{144}$ suggests that the relationships between ALDH, heat shock proteins, IFN-dependent pathways, and FA proteins should also be formally examined because they may be perturbed interdependently in FA cells.

\section{Macrophage dysfunction fans the flames}

One of the additional challenges associated with the aberrant FA inflammatory response is that FA mononuclear phagocytes, the progeny of FA HSCs, overproduce such cytokines in response to Toll-like receptor (TLR) activation ${ }^{104,130-132,145}$. So the pharmacological suppression of induced cytokine production or function may also reduce the stress on the HSPC pool. Some preliminary in vitro evidence of this had been reported ${ }^{145}$, but the scope of non-canonical signaling defects in FA is increasingly broad and involves interdependent pathways that pose a challenge for picking a particular molecular focus. Cross-talking environmental cues that induce inflammation, for example, regularly induce oxidative stress ${ }^{146-149}$ and enhance endogenous aldehyde loads ${ }^{82,84,86}$. Any one of these stressors can excessively suppress FA HSPCs and induce hyperactive inflammatory cytokine production in more well-differentiated myeloid cells.

\section{Mitophagic defects}

Some FA proteins now provide novel functional insights on longrecognized ties between inflammation and oxidative stress. Many of the non-canonical functions outlined in Table 2 have to do with controlling oxidative stress. For example, FANCC and FANCA normally participate in mitophagic responses by binding to Parkin (which itself is known to play a role in removing damaged mitochondria ${ }^{150}$ ), thereby clearing damaged mitochondria and reducing reactive oxygen species. Knockdown of $F A N C C,-F$, or $-L$ also leads to defective mitophagy ${ }^{101}$. Importantly, the function of FANCC in Parkin-mediated mitophagy is independent of its role in genomic DNA damage repair ${ }^{102}$. This point was recently demonstrated by using a FANCC mutant which does not rectify the dysfunction induced by FA mutations in the canonical pathway but does correct the Parkin-mediated mitophagic function of the protein ${ }^{102}$. This same FANCC mutant (c.67delG, also known as 322delG) also rescues defective STAT1 activation in FANCC-deficient cells without correcting the canonical pathway ${ }^{90,92}$ and is reportedly associated with a milder phenotype ${ }^{151}$, suggesting that parallel non-canonical pathways contribute to progression of BMF in FA.

\section{Experimental therapeutics}

In small-molecule therapy of FA, target candidates could include hyperactive signaling pathways in mutant cells that include p53 and p21 ${ }^{152}, \mathrm{PKR}^{91}, \mathrm{p} 38$ MAPK $^{130,141}$, the TLR pathway (p38 MAPK and MK2) $)^{130-132}$, and, most recently, hyperactive transforming growth factor beta (TGF $\beta$ ) signaling ${ }^{94}$. The ideal therapeutic agent would be one that in vivo: (1) reduces chromosomal breakage of all FA somatic cells exposed to endogenous and exogenous cross-linking agents, (2) enhances survival of FA cells exposed to genotoxic agents, (3) relieves the defects in FA HSCs in the ground state and in the face of inflammatory challenges, (4) reduces overproduction of or aberrant responses to reactive oxygen species, (5) enhances the metabolic inactivation of endogenous aldehydes, and (6) relieves the overproduction of inflammatory cytokines in more well-differentiated cells (hematopoietic and otherwise). In fact, the TGF $\beta$ 'pathway' results in many of these favorable responses in FA cells ${ }^{94}$, so it is currently an appealing target.

\section{Transforming growth factor beta signaling}

Antibody-mediated inhibition of the myelosuppressive protein TGF $\beta$ enhanced survival and performance of murine Fancd $2^{-1-}$ HSCs, increased the percentage of quiescent HSPCs in Fancd2deficient mice after exposure to polyinosinic:polycytidylic acid (pI:pC), and prevented pI:pC-induced marrow failure. Interestingly, the titer of DNA damage in mutant HSPCs was also reduced by the treatment with the antibody, a finding that led to the discovery that TGF $\beta$ inhibition enhanced homologous recombination repair of double-strand breaks (more likely to be error-free ${ }^{153}$ ) and decreased non-homologous end joining (error prone ${ }^{153}$ ) in FA cells and the confirmation that the same effect could be achieved by using a smallmolecule inhibitor (SD208) ${ }^{94}$. Why the TGF $\beta$ pathway is hyperactivated in FA cells is unclear, so a number of important questions remain to be addressed, including the potential impact on induced cytokine production in FA auxiliary cells (for example, macrophages) and on expression of various ALDHs in both auxiliary cells and HSCs. The role of non-SMAD signaling pathways ${ }^{154,155}$ ought to be tested, particularly since some of them are known to be involved in TLR hyper-responsiveness in FA macrophages $^{130,131}$ and in suppression of FA erythropoiesis in vitro ${ }^{145}$. Paracrine and autocrine sources of such factors must be identified and HSPC subtypes need to be carefully investigated because responses to TGF $\beta$ pathway disruption of various subsets can differ substantially ${ }^{156}$. Ruling out functional 
interference with other molecules of the 33-member TGF $\beta$ superfamily ${ }^{157}$ (for example, BMP-6) ${ }^{158,159}$ would help address safety concerns for any candidate molecule as would consideration of the anti- oncogenic function of TGF $\beta 1$ in modulating the transforming activity of HOXA $9^{160}$. This latter point is essential given the known high risk in FA patients of clonal evolution to myelodysplastic syndrome or acute myeloid leukemia.Nonetheless, although more work is required, the identification of the TGF $\beta$ pathway as a potential therapeutic target is buttressed by having met more standards for pharmacological candidacy than any other smallmolecule approach to date.

\section{Evolution and clonal selection}

Loss of the non-canonical functions of the FA proteins likely serves to exacerbate or activate processes that result in HSC dysfunction. Involvement of these proteins in protection from oxidative stress, inflammatory cues, and endogenous aldehydes and in facilitating selective autophagic responses occurs, at least in part, by way of parallel pathways that have evolved to protect the genome and protect germ cells ${ }^{106,161,162}$ and HSCs. This makes evolutionary sense. In multicellular organisms, this would simply ensure that loss of FA protein function would be attended by loss of fitness in the stem cell pool, limiting the rapid emergence of mutants. Unfortunately, in patients with FA, loss of HSC fitness leads most frequently to life-threatening BMF.

In nature, three things can happen to FA HSCs and two of them are undesirable. HSCs take the one good path least commonly. Here, a single FA HSC can mutate in a way that causes reversion of the mutation on one of the FA alleles (known as mosaicism $\left.{ }^{163-165}\right)$. In some cases in which mosaicism occurred in utero, the progeny of one mutant stem cell replaced the entire hematopoietic systems of twins, neither of whom ever developed $\mathrm{BMF}^{62}$. The second pathway, stem cell death and stem cell exhaustion, leads to the first of two undesirable outcomes, BMF. This is the most common early life-threatening complication in patients with FA. The third pathway is the selection of neoplastic stem cell clones. In this process, the loss of HSC fitness in the face of such an unstable genome creates an opportunity for selection of stem cell clones that have gained, through somatic mutations, a new capacity to either exploit or resist the very factors that had previously controlled their state of unfitness.

For example, FA hematopoietic progenitor cells are characteristically suppressed by TNF and IFN $\gamma$ in vitro during the non-clonal aplastic phase have been seen to proliferate abundantly in response to IFN $\gamma$ and TNF in vitro during the myelodysplastic (clonal) phase ${ }^{23}$. This process has also been confirmed in FA mice. Specifically, exposure of Fancc-deficient HSPCs to both growth factors and the inhibitory factor TNF in vitro suppressed their growth compared with the growth of wildtype cells, but over time, in some cases, rapid in vitro growth of FA-deficient cells ensued. The rapidly proliferating cells had clonal cytogenetic defects and had acquired resistance to TNF.
When transplanted into congenic wild-type mice, they induced fatal acute myelogenous leukemia ${ }^{166}$. The canonical pathway in these surviving leukemic cells was still fully defective but they had gained a survival advantage by 'quasi-adaptively' developing cytokine resistance.

The idea of multifunctionality of some of the FA proteins has met with some resistance in large part because the non-canonical processes affected can be either the cause of DNA damage or a consequence of it. To those who would argue that non-canonical pathways play a minor role or no role at all in reducing fitness of FA HSCs and that all non-canonical functions of FA proteins described to date are simply downstream consequences of DNA damage, I would raise two points. First, the natural selection of 'adapted' stem cell clones serves as evidence that non-canonical pathways are involved and contribute in a major way to the selection of neoplastic clonal hematopoiesis. Second, it is worth re-emphasizing that the murine models of FA develop truly fulminant BMF only when an inflammatory response is provoked in vivo ${ }^{108,123}$, so even if the non-canonical functions play a minor role, interdiction of the non-canonical phenomena that provoke stem cell attrition should have therapeutic value. In fact, Eklund's group has shown that this is the case at least in FA mice ${ }^{123}$. These observations have created some enthusiasm for attacking the molecular basis of stress intolerances in FA cells. They also create hope that by reducing selective pressures and selective inflammatory sweeps through the FA HSC pool, BMF could be prevented or forestalled and neoplastic clones would not emerge.

In summary, the advances in the FA field are exciting. They have resulted not only from a focus of the research community on the biochemistry of DNA damage repair but from an increasing recognition that the FA proteins are multifunctional and participate directly in biochemical pathways that effect protective responses to endogenous aldehydes, oxidative stress, inflammation, mitophagy, and virophagy. This increasingly complex expansion of the FA field may lead to more holistic clarity on molecular pathogenesis not only of BMF, leukemogenesis and cancer but of skeletal and cutaneous manifestations of this disease. Finally, today we recognize that this disease provides a uniquely informative window through which we can view more clearly the potential role of selective sweeps in the pathogenesis of myeloid neoplasms in the general population ${ }^{21,22,167}$.

\section{Competing interests}

The author declares that he has no competing interests.

\section{Grant information}

This work was supported by National Institutes of Health Grants (P01 HL048546, R01 CA 1138237, P30 CA69533) and the U.S. Department of Veterans Affairs (Merit Review).

The funders had no role in study design, data collection and analysis, decision to publish, or preparation of the manuscript. 
1. Fanconi G: Familiare infantile perniziosaartige anaemia (pernizioses blutbild und konstitution). Jahrb Kinderhilkd. 1927; 117: 257-280.

2. Latt $S A$, Stetten G, Juergens LA, et al.: Induction by alkylating agents of sister chromatid exchanges and chromatid breaks in Fanconi's anemia. Proc Nat Acad Sci U S A. 1975; 72(10): 4066-70.

PubMed Abstract | Publisher Full Text | Free Full Text

3. $\mathrm{F}$ Pinto $\mathrm{FO}$, Leblanc $T$, Chamousset $\mathrm{D}$, et al: Diagnosis of Fanconi anemia in patients with bone marrow failure. Haematologica. 2009; 94(4): 487-95. PubMed Abstract | Publisher Full Text | Free Full Text | F1000 Recommendation

4. Auerbach AD, Adler B, Chaganti RS: Prenatal and postnatal diagnosis and carrier detection of Fanconi anemia by a cytogenetic method. Pediatrics. 1981; 67(1): 128-35

PubMed Abstract

5. Aker M, Varadi G, Slavin S, et al.: Fludarabine-based protocol for human umbilical cord blood transplantation in children with Fanconi anemia. J Pediatr Hematol Oncol. 1999; 21(3): 237-9.

PubMed Abstract

6. Boyer MW, Gross TG, Loechelt B, et al:: Low risk of graft-versus-host disease with transplantation of CD34 selected peripheral blood progenitor cells from alternative donors for Fanconi anemia. J Pediatr Hematol Oncol. 2003; 25(11): $890-5$.

PubMed Abstract | Publisher Full Text

7. Chaudhury S, Auerbach AD, Kernan NA, et al.: Fludarabine-based cytoreductive regimen and T-cell-depleted grafts from alternative donors for the treatment of high-risk patients with Fanconi anaemia. Br J Haematol. 2008; 140(6): 644-55. PubMed Abstract | Publisher Full Tex

8. F Dufour C: How I manage patients with Fanconi anaemia. $\mathrm{Br} J$ Haematol. 2017; 178(1): 32-47.

PubMed Abstract | Publisher Full Text | F1000 Recommendation

9. Gluckman E, Broxmeyer HA, Auerbach AD, et al:: Hematopoietic reconstitution in a patient with Fanconi's anemia by means of umbilical-cord blood from an HLA-identical sibling. N Engl J Med. 1989; 321(17): 1174-8. PubMed Abstract | Publisher Full Text

10. MacMillan ML, Wagner JE: Haematopoeitic cell transplantation for Fancon anaemia - when and how? Br J Haematol. 2010; 149(1): 14-21. PubMed Abstract | Publisher Full Text

11. F MacMillan ML, DeFor TE, Young JA, et al:: Alternative donor hematopoietic cell transplantation for Fanconi anemia. Blood. 2015; 125(24): 3798-804. PubMed Abstract | Publisher Full Text | Free Full Text | F1000 Recommendation

12. Socié G, Gluckman E, Raynal B, et al.: Bone marrow transplantation for Fanconi anemia using low-dose cyclophosphamide/thoracoabdominal irradiation as conditioning regimen: chimerism study by the polymerase chain reaction. Blood. 1993; 82(7): 2249-56.

PubMed Abstract

13. Smith AR, Wagner JE: Current clinical management of Fanconi anemia. Expert Rev Hematol. 2012; 5(5): 513-22.

PubMed Abstract | Publisher Full Text

14. Anur P, Friedman DN, Sklar C, et al.: Late effects in patients with Fanconi anemia following allogeneic hematopoietic stem cell transplantation from alternative donors. Bone Marrow Transplant. 2016; 51(7): 938-44. PubMed Abstract | Publisher Full Text | Free Full Text

15. Bonfim C, Ribeiro L, Nichele S, et al:: Long-term Survival, Organ Function, and Malignancy after Hematopoietic Stem Cell Transplantation for Fanconi Anemia. Biol Blood Marrow Transplant. 2016; 22(7): 1257-63. PubMed Abstract | Publisher Full Text

16. Dietz AC, Mehta PA, Vlachos A, et al:: Current Knowledge and Priorities for Future Research in Late Effects after Hematopoietic Cell Transplantation for Inherited Bone Marrow Failure Syndromes: Consensus Statement from the Second Pediatric Blood and Marrow Transplant Consortium International Conference on Late Effects after Pediatric Hematopoietic Cell Transplantation Biol Blood Marrow Transplant. 2017; 23(5): 726-35. PubMed Abstract | Publisher Full Text | Free Full Text

17. Dietz AC, Savage SA, Vlachos A, et al.: Late Effects Screening Guidelines after Hematopoietic Cell Transplantation for Inherited Bone Marrow Failure Syndromes: Consensus Statement From the Second Pediatric Blood and Marrow Transplant Consortium International Conference on Late Effects After Pediatric HCT. Biol Blood Marrow Transplant. 2017; 23(9): 1422-8. PubMed Abstract | Publisher Full Text | Free Full Text

18. Strathdee CA, Gavish H, Shannon WR, et al:: Cloning of cDNAs for Fanconi's anaemia by functional complementation. Nature. 1992; 356(6372): 763-7. PubMed Abstract | Publisher Full Tex

19. Strathdee CA, Gavish H, Shannon WR, et al.: Cloning of cDNAs for Fanconi's anaemia by functional complementation. Nature. 1992; 358(6385): 434. PubMed Abstract | Publisher Full Tex

20. F Knies K, Inano S, Ramírez MJ, et al.: Biallelic mutations in the ubiquitin ligase RFWD3 cause Fanconi anemia. J Clin Invest. 2017; 127(8): 3013-27. PubMed Abstract | Publisher Full Text | Free Full Text | F1000 Recommendation
21. Bagby GC, Fleischman AG: The stem cell fitness landscape and pathways of molecular leukemogenesis. Front Biosci (Schol Ed). 2011; 3: 487-500. PubMed Abstract | Publisher Full Text

22. Fleischman AG, Aichberger KJ, Luty SB, et al:: TNF $\alpha$ facilitates clonal expansion of JAK2V617F positive cells in myeloproliferative neoplasms. Blood. 2011; 118(24): 6392-8.

PubMed Abstract | Publisher Full Text | Free Full Text

23. Lensch MW, Rathbun RK, Olson SB, et al:: Selective pressure as an essential force in molecular evolution of myeloid leukemic clones: a view from the window of Fanconi anemia. Leukemia. 1999; 13(11): 1784-9. PubMed Abstract | Publisher Full Text

24. Lensch MW, Tischkowitz M, Christianson TA, et al:: Acquired FANCA dysfunction and cytogenetic instability in adult acute myelogenous leukemia. Blood. 2003; 102(1): 7-16.

PubMed Abstract | Publisher Full Text

25. Meetei AR, Levitus M, Xue Y, et al.: X-linked inheritance of Fanconi anemia complementation group B. Nat Genet. 2004; 36(11): 1219-24. PubMed Abstract | Publisher Full Text

26. Wang AT, Kim T, Wagner JE, et al:: A Dominant Mutation in Human RAD51 Reveals Its Function in DNA Interstrand Crosslink Repair Independent of Homologous Recombination. Mol Cell. 2015; 59(3): 478-90. PubMed Abstract | Publisher Full Text | Free Full Text

27. F Bogliolo M, Bluteau D, Lespinasse J, et al.: Biallelic truncating FANCM mutations cause early-onset cancer but not Fanconi anemia. Genet Med. 2017. PubMed Abstract | Publisher Full Text | F1000 Recommendation

28. Bakker ST, van de Vrugt HJ, Rooimans MA, et al.: Fancm-deficient mice reveal unique features of Fanconi anemia complementation group M. Hum Mol Genet. 2009; 18(18): 3484-95

PubMed Abstract | Publisher Full Text

29. Lo Ten Foe JR, Rooimans MA, Bosnoyan-Collins L, et al.: Expression cloning of a cDNA for the major Fanconi anaemia gene, FAA. Nat Genet. 1996; 14(3): 320-3. PubMed Abstract | Publisher Full Text

30. de Winter JP, Waisfisz $Q$, Rooimans MA, et al: The Fanconi anaemia group $G$ gene FANCG is identical with XRCC9. Nat Genet. 1998; 20(3): 281-3. PubMed Abstract | Publisher Full Text

31. de Winter JP, Léveillé $F$, van Berkel CG, et al:: Isolation of a cDNA representing the Fanconi anemia complementation group E gene. Am J Hum Genet. 2000; 67(5): 1306-8 PubMed Abstract | Publisher Full Text | Free Full Text

32. de Winter JP, Rooimans MA, van der Weel L, et al:: The Fanconi anaemia gene FANCF encodes a novel protein with homology to ROM. Nat Genet. 2000; 24(1): $15-6$. PubMed Abstract | Publisher Full Text

33. $F$ Meetei AR de Winter JP, Medhurst AL, et al: A novel ubiquitin ligase is deficient in Fanconi anemia. Nat Genet. 2003; 35(2): 165-70. PubMed Abstract | Publisher Full Text | F1000 Recommendation

34. F Meetei AR, Medhurst AL, Ling C, et al:: A human ortholog of archaeal DNA repair protein Hef is defective in Fanconi anemia complementation group $\mathrm{M}$. Nat Genet. 2005; 37(9): 958-63. PubMed Abstract | Publisher Full Text | Free Full Text | F1000 Recommendation

35. F Smogorzewska A, Matsuoka S, Vinciguerra $P$, et al.: Identification of the FANCI protein, a monoubiquitinated FANCD2 paralog required for DNA repair Cell. 2007; 129(2): 289-301.

PubMed Abstract | Publisher Full Text | Free Full Text | F1000 Recommendation

36. Dorsman JC, Levitus M, Rockx D, et al.: Identification of the Fanconi anemia complementation group I gene, FANCI. Cell Oncol. 2007; 29(3): 211-8. PubMed Abstract | Free Full Text

37. Timmers C, Taniguchi T, Hejna J, et al:: Positional cloning of a novel Fancon anemia gene, FANCD2. Mol Cell. 2001; 7(2): 241-8. PubMed Abstract | Publisher Full Text

38. F Howlett NG, Taniguchi T, Olson S, et al:: Biallelic inactivation of BRCA2 in Fanconi anemia. Science. 2002; 297(5581): 606-9. PubMed Abstract | Publisher Full Text | F1000 Recommendation

39. Levitus M, Waisfisz Q, Godthelp BC, et al:: The DNA helicase BRIP1 is defective in Fanconi anemia complementation group J. Nat Genet. 2005; 37(9): 934-5. PubMed Abstract | Publisher Full Text

40. Levran O, Attwooll C, Henry RT, et al.: The BRCA1-interacting helicase BRIP1 is deficient in Fanconi anemia. Nat Genet. 2005; 37(9): 931-3. PubMed Abstract | Publisher Full Text

41. Xia B, Dorsman JC, Ameziane N, et al.: Fanconi anemia is associated with a defect in the BRCA2 partner PALB2. Nat Genet. 2007; 39(2): 159-61. PubMed Abstract| Publisher Full Text

42. F Vaz F, Hanenberg H, Schuster B, et al.: Mutation of the RAD51C gene in a Fanconi anemia-like disorder. Nat Genet. 2010; 42(5): 406-9. PubMed Abstract | Publisher Full Text | F1000 Recommendation 
43. Kim Y, Lach FP, Desetty R, et al:: Mutations of the SLX4 gene in Fanconi anemia. Nat Genet. 2011; 43(2): 142-6.

PubMed Abstract | Publisher Full Text | Free Full Text

44. F Stoepker C, Hain K, Schuster B, et al:: SLX4, a coordinator of structurespecific endonucleases, is mutated in a new Fanconi anemia subtype. Nat Genet. 2011; 43(2): 138-41.

PubMed Abstract | Publisher Full Text | F1000 Recommendation

45. F Bogliolo M, Schuster B, Stoepker C, et al:: Mutations in ERCC4, encoding the DNA-repair endonuclease XPF, cause Fanconi anemia. Am J Hum Genet. 2013; 92(5): 800-6.

PubMed Abstract | Publisher Full Text | Free Full Text | F1000 Recommendation

46. Ameziane N, May P, Haitjema A, et al:: A novel Fanconi anaemia subtype associated with a dominant-negative mutation in RAD51. Nat Commun. 2015; 6: 8829.

PubMed Abstract | Publisher Full Text | Free Full Text

47. Domchek SM, Tang J, Stopfer J, et al:: Biallelic deleterious BRCA1 mutations in a woman with early-onset ovarian cancer. Cancer Discov. 2013; 3(4): 399-405. PubMed Abstract | Publisher Full Text | Free Full Text

48. Sawyer SL, Tian L, Kähkönen M, et al.: Biallelic mutations in BRCA1 cause a new Fanconi anemia subtype. Cancer Discov. 2015; 5(2): 135-42. PubMed Abstract | Publisher Full Text | Free Full Text

49. Hira A, Yoshida K, Sato K, et al:: Mutations in the gene encoding the E2 conjugating enzyme UBE2T cause Fanconi anemia. Am J Hum Genet. 2015; 96(6): 1001-7.

PubMed Abstract | Publisher Full Text | Free Full Text

50. Park J Virts EL, Jankowska $A$, et al: Complementation of hypersensitivity to DNA interstrand crosslinking agents demonstrates that XRCC2 is a Fancon anaemia gene. J Med Genet. 2016; 53(10): 672-80.

PubMed Abstract | Publisher Full Text | Free Full Text

51. Shamseldin HE, Elfaki M, Alkuraya FS: Exome sequencing reveals a novel Fanconi group defined by XRCC2 mutation. J Med Genet. 2012; 49(3): 184-6. PubMed Abstract | Publisher Full Text

52. Bluteau D, Masliah-Planchon J, Clairmont C, et al:: Biallelic inactivation of REV7 is associated with Fanconi anemia. J Clin Invest. 2016; 126(9): 3580-4. PubMed Abstract | Publisher Full Text | Free Full Text

53. Garcia-Higuera I, Taniguchi T, Ganesan S, et al.: Interaction of the Fanconi anemia proteins and BRCA1 in a common pathway. Mol Cell. 2001; 7(2): 249-62. PubMed Abstract | Publisher Full Text

54. Shimamura A, Montes de Oca R, Svenson JL, et al:: A novel diagnostic screen for defects in the Fanconi anemia pathway. Blood. 2002; 100(13): 4649-54. PubMed Abstract | Publisher Full Text

55. Sims AE, Spiteri E, Sims RJ 3rd, et al:: $\mathrm{FANCl}$ is a second monoubiquitinated member of the Fanconi anemia pathway. Nat Struct Mol Biol. 2007; 14(6): 564-7. PubMed Abstract | Publisher Full Text

56. F Alpi AF, Pace PE, Babu MM, et al.: Mechanistic insight into site-restricted monoubiquitination of FANCD2 by Ube2t, FANCL, and FANCI. Mol Cell. 2008; 32(6): 767-77.

PubMed Abstract | Publisher Full Text | F1000 Recommendation

57. Taniguchi T, Dandrea AD: Molecular pathogenesis of fanconi anemia. Int Hematol. 2002; 75(2): 123-8.

PubMed Abstract | Publisher Full Text

58. F Cheung RS, Taniguchi T: Recent insights into the molecular basis of Fanconi anemia: genes, modifiers, and drivers. Int J Hematol. 2017; 106(3): 335-44.

PubMed Abstract | Publisher Full Text | F1000 Recommendation

59. Nalepa G, Enzor R, Sun Z, et al.: Fanconi anemia signaling network regulates the spindle assembly checkpoint. J Clin Invest. 2013; 123(9): 3839-47. PubMed Abstract | Publisher Full Text | Free Full Text

60. F Chan KL, Palmai-Pallag T, Ying S, et al.: Replication stress induces sisterchromatid bridging at fragile site loci in mitosis. Nat Cell Biol. 2009; 11(6): 753-60.

PubMed Abstract | Publisher Full Text | F1000 Recommendation

61. Naim V, Rosselli F: The FANC pathway and BLM collaborate during mitosis to prevent micro-nucleation and chromosome abnormalities. Nat Cell Biol. 2009; 11(6): 761-8 PubMed Abstract | Publisher Full Tex

62. F Mankad A, Taniguchi T, Cox B, et al:: Natural gene therapy in monozygotic twins with Fanconi anemia. Blood. 2006; 107(8): 3084-90. PubMed Abstract | Publisher Full Text | Free Full Text | F1000 Recommendation

63. Tulpule A, Lensch MW, Miller JD, et al: Knockdown of Fanconi anemia genes in human embryonic stem cells reveals early developmental defects in the hematopoietic lineage. Blood. 2010; 115(17): 3453-62. PubMed Abstract | Publisher Full Text | Free Full Text

64. Kamimae-Lanning AN, Goloviznina NA, Kurre $P$, et al:: Fetal origins of hematopoietic failure in a murine model of Fanconi anemia. Blood. 2013; 121(11): 2008-12.

PubMed Abstract | Publisher Full Text | Free Full Text

65. F Suzuki S, Racine RR, Manalo NA, et al.: Impairment of fetal hematopoietic stem cell function in the absence of Fancd2. Exp Hematol. 2017; 48: 79-86. PubMed Abstract | Publisher Full Text | Free Full Text | F1000 Recommendation
66. Almeida-Porada G, Atala A, Porada CD: In utero stem cell transplantation and gene therapy: rationale, history, and recent advances toward clinical application. Mol Ther Methods Clin Dev. 2016; 5: 16020.

PubMed Abstract | Publisher Full Text | Free Full Text

67. Battaile KP, Bateman RL, Mortimer D, et al:: In vivo selection of wild-type hematopoietic stem cells in a murine model of Fanconi anemia. Blood. 1999; 94(6): 2151-8

PubMed Abstract

68. Croop JM: Gene therapy for fanconi anemia. Curr Hematol Rep. 2003; 2(4) 335-40.

PubMed Abstract

69. F Fernández-García M, Luisa Lamana M, Hernando-Rodríguez M, et al.: mproved Hematopoietic Gene Therapy in a Mouse Model of Fanconi Anemia Mediated by Mesenchymal Stromal Cells. Hum Gene Ther. 2017. PubMed Abstract | Publisher Full Text | F1000 Recommendation

70. Liu JM, Young NS, Walsh CE, et al.: Retroviral mediated gene transfer of the Fanconi anemia complementation group $\mathrm{C}$ gene to hematopoietic progenitors of group C patients. Hum Gene Ther. 1997; 8(14): 1715-30.

PubMed Abstract | Publisher Full Text

71. F Verhoeyen E, Roman-Rodriguez FJ, Cosset FL, et al:: Gene Therapy in Fanconi Anemia: A Matter of Time, Safety and Gene Transfer Tool Efficiency. Curr Gene Ther. 2017; 16(5): 297-308.

PubMed Abstract | Publisher Full Text | F1000 Recommendation

72. Williams DA, Croop J, Kelly P: Gene therapy in the treatment of Fanconi anemia, a progressive bone marrow failure syndrome. Curr Opin Mol Ther. 2005; 7(5): 461-6.

PubMed Abstract

73. Adair JE, Sevilla J, Heredia CD, et al:: Lessons Learned from Two Decades of Clinical Trial Experience in Gene Therapy for Fanconi Anemia. Curr Gene Ther. 2017; 16(5): 338-48.

PubMed Abstract | Publisher Full Text

74. Rosado IV, Langevin F, Crossan GP, et al:: Formaldehyde catabolism is essential in cells deficient for the Fanconi anemia DNA-repair pathway. Nat Struct Mol Biol. 2011; 18(12): 1432-4.

PubMed Abstract | Publisher Full Text

75. F Pontel LB, Rosado IV, Burgos-Barragan G, et al:: Endogenous Formaldehyde s a Hematopoietic Stem Cell Genotoxin and Metabolic Carcinogen. Mol Cell. 2015; 60(1): 177-88.

PubMed Abstract | Publisher Full Text | Free Full Text | F1000 Recommendation

76. F Langevin F, Crossan GP, Rosado IV, et al:: Fancd2 counteracts the toxic effects of naturally produced aldehydes in mice. Nature. 2011; 475(7354): 53-8. PubMed Abstract | Publisher Full Text | F1000 Recommendation

77. Hira A, Yabe H, Yoshida K, et al.: Variant ALDH2 is associated with accelerated progression of bone marrow failure in Japanese Fanconi anemia patients. Blood. 2013; 122(18): 3206-9.

PubMed Abstract | Publisher Full Text | Free Full Text

78. Garaycoechea JI, Patel $\mathrm{KJ}$ : Why does the bone marrow fail in Fanconi anemia? Blood. 2014; 123(1): 26-34.

PubMed Abstract | Publisher Full Text

79. Brooks PJ, Zakhari S: Acetaldehyde and the genome: beyond nuclear DNA adducts and carcinogenesis. Environ Mol Mutagen. 2014; 55(2): 77-91. PubMed Abstract | Publisher Full Text

80. Antoniak DT, Duryee MJ, Mikuls TR, et al:: Aldehyde-modified proteins as mediators of early inflammation in atherosclerotic disease. Free Radic Biol Med. 2015; 89: 409-18

PubMed Abstract | Publisher Full Text

81. Go YM, Halvey PJ, Hansen JM, et al:: Reactive aldehyde modification of thioredoxin-1 activates early steps of inflammation and cell adhesion. $\mathrm{Am}$ Pathol. 2007; 171(5): 1670-81.

PubMed Abstract | Publisher Full Text | Free Full Text

82. Hill GE, Miller JA, Baxter BT, et al:: Association of malondialdehydeacetaldehyde (MAA) adducted proteins with atherosclerotic-induced vascular inflammatory injury. Atherosclerosis. 1998; 141(1): 107-16. PubMed Abstract | Publisher Full Text

83. Donohue E, Balgi AD, Komatsu M, et al: Induction of Covalently Crosslinked p62 Oligomers with Reduced Binding to Polyubiquitinated Proteins by the Autophagy Inhibitor Verteporfin. PLOS One. 2014; 9(12): e114964. PubMed Abstract | Publisher Full Text | Free Full Text

84. Ito $\mathrm{K}$, Zolfaghari $\mathrm{R}, \mathrm{Hao} \mathrm{L}$, et al.: Inflammation rapidly modulates the expression of ALDH1A1 (RALDH1) and vimentin in the liver and hepatic macrophages of rats in vivo. Nutr Metab (Lond). 2014; 11: 54 PubMed Abstract | Publisher Full Text | Free Full Text

85. Magnusson MK, Brynjólfsson SF, Dige A, et al.: Macrophage and dendritic cell subsets in IBD: $\mathrm{ALDH}^{+}$cells are reduced in colon tissue of patients with ulcerative colitis regardless of inflammation. Mucosal Immunol. 2016; 9(1): 171-82.

PubMed Abstract | Publisher Full Text | Free Full Text

86. Cohen SB, Denkers EY: Impact of Toxoplasma gondii on Dendritic Cell Subset Function in the Intestinal Mucosa. J Immunol. 2015; 195(6): 2754-62. PubMed Abstract | Publisher Full Text | Free Full Text

87. Hurst RJ, Else KJ: The retinoic acid-producing capacity of gut dendritic cells 
and macrophages is reduced during persistent $T$. muris infection. Parasite Immunol. 2013; 35(7-8): 229-33.

PubMed Abstract | Publisher Full Text | Free Full Text

88. F Van Wassenhove LD, Mochly-Rosen D, Weinberg KI: Aldehyde dehydrogenase 2 in aplastic anemia, Fanconi anemia and hematopoietic stem cells. Mol Genet Metab. 2016; 119(1-2): 28-36.

PubMed Abstract | Publisher Full Text | Free Full Text | F1000 Recommendation

89. Kim Y, Spitz GS, Veturi U, et al.: Regulation of multiple DNA repair pathways by the Fanconi anemia protein SLX4. Blood. 2013; 121(1): 54-63.

PubMed Abstract | Publisher Full Text | Free Full Text

90. Pang Q, Fagerlie S, Christianson TA, et al:: The Fanconi anemia protein FANCC binds to and facilitates the activation of STAT1 by gamma interferon and hematopoietic growth factors. Mol Cell Biol. 2000; 20(13): 4724-35. PubMed Abstract | Publisher Full Text | Free Full Text

91. Pang Q, Keeble W, Diaz J, et al.: Role of double-stranded RNA-dependent protein kinase in mediating hypersensitivity of Fanconi anemia complementation group $\mathrm{C}$ cells to interferon gamma, tumor necrosis factoralpha, and double-stranded RNA. Blood. 2001; 97(6): 1644-52. PubMed Abstract | Publisher Full Text

92. Pang Q, Christianson TA, Keeble W, et al:: The Fanconi anemia complementation group C gene product: structural evidence of multifunctionality. Blood. 2001; 98(5): 1392-401.

PubMed Abstract | Publisher Full Text

93. Pang Q, Keeble W, Christianson TA, et al:: FANCC interacts with Hsp70 to protect hematopoietic cells from IFN-gamma/TNF-alpha-mediated cytotoxicity. EMBO J. 2001; 20(16): 4478-89.

PubMed Abstract | Publisher Full Text | Free Full Text

94. F Zhang H, Kozono DE, O'Connor KW, et al:: TGF- $\beta$ Inhibition Rescues Hematopoietic Stem Cell Defects and Bone Marrow Failure in Fanconi Anemia. Cell Stem Cell. 2016; 18(5): 668-81.

PubMed Abstract | Publisher Full Text | Free Full Text | F1000 Recommendation

95. Bagby GC: Multifunctional Fanconi proteins, inflammation and the Fanconi phenotype. EBioMedicine. 2016; 8: 10-11

PubMed Abstract | Publisher Full Text | Free Full Text

96. Guillemette $\mathrm{S}$, Branagan A, Peng M, et al: FANCJ localization by mismatch repair is vital to maintain genomic integrity after UV irradiation. Cancer Res. 2014; 74(3): 932-44.

PubMed Abstract | Publisher Full Text | Free Full Text

97. F Moriel-Carretero M, Ovejero S, Gérus-Durand M, et al.: Fanconi anemia FANCD2 and $\mathrm{FANCI}$ proteins regulate the nuclear dynamics of splicing factors. $J$ Cell Biol. 2017; 216(12): 4007-26.

PubMed Abstract | Publisher Full Text | Free Full Text | F1000 Recommendation

98. Mukhopadhyay SS, Leung KS, Hicks MJ, et al:: Defective mitochondrial peroxiredoxin-3 results in sensitivity to oxidative stress in Fanconi anemia. J Cell Biol. 2006; 175(2): 225-35.

PubMed Abstract | Publisher Full Text | Free Full Text

99. Park JY, Zhang F, Andreassen PR: PALB2: the hub of a network of tumor suppressors involved in DNA damage responses. Biochim Biophys Acta. 2014; 1846(1): 263-75

PubMed Abstract | Publisher Full Text | Free Full Text

100. $\mathrm{F}$ Zhang $\mathrm{T}$, Du W, Wilson $\mathrm{AF}$, et al:: Fancd2 in vivo interaction network reveals a non-canonical role in mitochondrial function. Sci Rep. 2017; 7: 45626 . PubMed Abstract | Publisher Full Text | Free Full Text | F1000 Recommendation

101. F Orvedahl A, Sumpter R Jr, Xiao G, et al:: Image-based genome-wide siRNA screen identifies selective autophagy factors. Nature. 2011; 480(7375): 113-7. PubMed Abstract | Publisher Full Text | Free Full Text | F1000 Recommendation

102. F Sumpter R Jr, Sirasanagandla S, Fernández ÁF, et al:: Fanconi Anemia Proteins Function in Mitophagy and Immunity. Cell. 2016; 165(4): 867-81. PubMed Abstract | Publisher Full Text | Free Full Text | F1000 Recommendation

103. F Sumpter R Jr, Levine B: Emerging functions of the Fanconi anemia pathway at a glance. $J$ Cell Sci. 2017; 130(16): 2657-62.

PubMed Abstract | Publisher Full Text | Free Full Text | F1000 Recommendation

104. Garbati MR, Hays LE, Rathbun RK, et al.: Cytokine overproduction and crosslinker hypersensitivity are unlinked in Fanconi anemia macrophages. J Leukoc Biol. 2016; 99(3): 455-65. PubMed Abstract | Publisher Full Text

105. Fagerlie SR, Diaz J, Christianson TA, et al:: Functional correction of FA-C cells with FANCC suppresses the expression of interferon gamma-inducible genes. Blood. 2001; 97(10): 3017-24.

PubMed Abstract | Publisher Full Text

106. Whitney MA, Royle G, Low MJ, et al:: Germ cell defects and hematopoietic hypersensitivity to gamma-interferon in mice with a targeted disruption of the Fanconi anemia C gene. Blood. 1996; 88(1): 49-58. PubMed Abstract

107. Pang $Q$, Christianson TA, Keeble W, et al:: The anti-apoptotic function of Hsp70 in the interferon-inducible double-stranded RNA-dependent protein kinasemediated death signaling pathway requires the Fanconi anemia protein, FANCC. J Biol Chem. 2002; 277(51): 49638-43.

PubMed Abstract | Publisher Full Text

108. F Walter D, Lier A, Geiselhart A, et al:: Exit from dormancy provokes DNA-damage-induced attrition in haematopoietic stem cells. Nature. 2015
520(7548): 549-52.

PubMed Abstract | Publisher Full Text | F1000 Recommendation

109. Bijangi-Vishehsaraei K, Saadatzadeh MR, Werne A, et al.: Enhanced TNF-alphainduced apoptosis in Fanconi anemia type C-deficient cells is dependent on apoptosis signal-regulating kinase 1. Blood. 2005; 106(13): 4124-30. PubMed Abstract | Publisher Full Text | Free Full Text

110. Cumming $\mathrm{RC}$, Lightfoot $\mathrm{J}$, Beard $\mathrm{K}$, et al:: Fanconi anemia group $\mathrm{C}$ protein prevents apoptosis in hematopoietic cells through redox regulation of GSTP1. Nat Med. 2001; 7(7): 814-20.

PubMed Abstract | Publisher Full Text

111. Futaki M, Igarashi T, Watanabe $S$, et al.: The FANCG Fanconi anemia protein interacts with CYP2E1: possible role in protection against oxidative DNA damage. Carcinogenesis. 2002; 23(1): 67-72. PubMed Abstract | Publisher Full Text

112. Gille JJ, Wortelboer HM, Joenje $\mathrm{H}$ : Antioxidant status of Fanconi anemia fibroblasts. Hum Genet. 1987; 77(1): 28-31. PubMed Abstract | Publisher Full Text

113. Kontou M, Adelfalk C, Hirsch-Kauffmann M, et al:: Suboptimal action of NFkappaB in Fanconi anemia cells results from low levels of thioredoxin. Biol Chem. 2003: 384(10-11): 1501-7. PubMed Abstract | Publisher Full Text

114. Li J, Pang Q: Oxidative stress-associated protein tyrosine kinases and phosphatases in Fanconi anemia. Antioxid Redox Signal. 2014; 20(14): 2290-301. PubMed Abstract | Publisher Full Text | Free Full Text

115. Pagano $G$, Degan $P$, d'Ischia $M$, et al:: Oxidative stress as a multiple effector in Fanconi anaemia clinical phenotype. Eur J Haematol. 2005; 75(2): 93-100. PubMed Abstract | Publisher Full Text

116. Ruppitsch W, Meisslitzer C, Hirsch-Kauffmann M, et al:: Overexpression of thioredoxin in Fanconi anemia fibroblasts prevents the cytotoxic and DNA damaging effect of mitomycin C and diepoxybutane. FEBS Lett. 1998; 422(1): 99-102.

PubMed Abstract | Publisher Full Text

117. Saadatzadeh MR, Bijangi-Vishehsaraei K, Hong $P$, et al.: Oxidant hypersensitivity of Fanconi anemia type C-deficient cells is dependent on a redox-regulated apoptotic pathway. J Biol Chem. 2004; 279(16): 16805-12. PubMed Abstract | Publisher Full Text

118. Tacconi EM, Lai X, Folio C, et al.: BRCA1 and BRCA2 tumor suppressors protect against endogenous acetaldehyde toxicity. EMBO Mol Med. 2017; 9(10) 1398-414.

PubMed Abstract | Publisher Full Text | Free Full Text

119. F Ho TT, Warr MR, Adelman ER, et al.: Autophagy maintains the metabolism and function of young and old stem cells. Nature. 2017; 543(7644): 205-10. PubMed Abstract | Publisher Full Text | Free Full Text | F1000 Recommendation

120. Lier A, Walter D, Geiselhart A, et al:: Stress-induced exit from dormancy alters redox signaling in HSCs, resulting in de novo DNA damage and bone marrow failure in the absence of a functional fanconi anemia signaling pathway. Exp Hematol. 2014; 42(8): S45. Publisher Full Text

121. Chen C, Liu Y, Liu Y, et al:: Mammalian target of rapamycin activation underlies HSC defects in autoimmune disease and inflammation in mice. $J$ Clin Invest. 2010; 120(11): 4091-101.

PubMed Abstract | Publisher Full Text | Free Full Text

122. Beere HM: Stressed to death: regulation of apoptotic signaling pathways by the heat shock proteins. Sci STKE. 2001; 2001(93): re1. PubMed Abstract | Publisher Full Text

123. Hu L, Huang W, Hjort $\mathrm{E}$, et al: Increased Fanconi $\mathrm{C}$ expression contributes to the emergency granulopoiesis response. J Clin Invest. 2013; 123(9): 3952-66. PubMed Abstract | Publisher Full Text | Free Full Text

124. Lin FC, Karwan M, Saleh B, et al.: IFN- $\gamma$ causes aplastic anemia by altering hematopoietic stem/progenitor cell composition and disrupting lineage differentiation. Blood. 2014; 124(25): 3699-708. PubMed Abstract | Publisher Full Text | Free Full Text

125. Nakao S, Yamaguchi M, Shiobara S, et al.: Interferon-gamma gene expression in unstimulated bone marrow mononuclear cells predicts a good response to cyclosporine therapy in aplastic anemia. Blood. 1992; 79(10): 2532-5. PubMed Abstract

126. F Chen J, Feng $\mathrm{X}$, Desierto MJ, et al.: IFN- $\gamma$-mediated hematopoietic cell destruction in murine models of immune-mediated bone marrow failure. Blood. 2015; 126(24): 2621-31.

PubMed Abstract | Publisher Full Text | Free Full Text | F1000 Recommendation

127. Grompe M, Whitney MA, Low $\mathrm{M}$, et al.: Progenitor cell dysfunction in mice with Fanconi anemia group C gene disruption [abstract]. Blood. 1995; 86: 246a.

128. Du W, Rani R, Sipple J, et al:: The FA pathway counteracts oxidative stress through selective protection of antioxidant defense gene promoters. Blood. 2012; 119(18): 4142-51. PubMed Abstract | Publisher Full Text | Free Full Text

129. Li J, Du W, Maynard S, et al.: Oxidative stress-specific interaction between FANCD2 and FOXO3a. Blood. 2010; 115(8): 1545-8. PubMed Abstract | Publisher Full Text | Free Full Text

130. Garbati MR, Hays LE, Keeble W, et al.: FANCA and FANCC modulate TLR and p38 MAPK-dependent expression of IL-1 $\beta$ in macrophages. Blood. 2013; 122(18): 3197-205

PubMed Abstract | Publisher Full Text | Free Full Text 
131. Anur P, Yates J, Garbati MR, et al.: p38 MAPK inhibition suppresses the TLRhypersensitive phenotype in FANCC- and FANCA-deficient mononuclear phagocytes. Blood. 2012; 119(9): 1992-2002. PubMed Abstract | Publisher Full Text | Free Full Text

132. Vanderwerf SM, Svahn J, Olson S, et al.: TLR8-dependent TNF-(alpha) overexpression in Fanconi anemia group C cells. Blood. 2009; 114(26): 5290-8. PubMed Abstract | Publisher Full Text | Free Full Text

133. Huard CC, Tremblay CS, Magron A, et al:: The Fanconi anemia pathway has a dual function in Dickkopf-1 transcriptional repression. Proc Natl Acad Sci U S A. 2014; 111(6): 2152-7.

PubMed Abstract | Publisher Full Text | Free Full Text

134. Dao KT, Rotelli MD, Petersen $\mathrm{CL}$, et al:: FANCL ubiquitinates $\beta$-catenin and enhances its nuclear function. Blood. 2012; 120(2): 323-34. PubMed Abstract | Publisher Full Text | Free Full Text

135. Brégnard C, Guerra J, Déjardin S, et al:: Upregulated LINE-1 Activity in the Fanconi Anemia Cancer Susceptibility Syndrome Leads to Spontaneous Pro-inflammatory Cytokine Production. EBioMedicine. 2016; 8: 184-94. PubMed Abstract | Publisher Full Text | Free Full Text

136. Kumari U, Ya Jun W, Huat Bay B, et al.: Evidence of mitochondrial dysfunction and impaired ROS detoxifying machinery in Fanconi anemia cells. Oncogene. 2014; 33(2): 165-72.

PubMed Abstract | Publisher Full Text

137. Fang HY, Chang $\mathrm{CL}, \mathrm{Hsu} \mathrm{SH}$, et al.: ATPase family AAA domain-containing $\mathbf{3 A}$ is a novel anti-apoptotic factor in lung adenocarcinoma cells. J Cell Sci. 2010; 123(Pt 7): 1171-80. PubMed Abstract | Publisher Full Text

138. Matsunawa M, Yamamoto R, Sanada M, et al.: Haploinsufficiency of Sf3b1 leads to compromised stem cell function but not to myelodysplasia. Leukemia. 2014 28(9): 1844-50.

PubMed Abstract | Publisher Full Text

139. Pang $Q$, Andreassen PR: Fanconi anemia proteins and endogenous stresses. Mutat Res. 2009; 668(1-2): 42-53. PubMed Abstract | Publisher Full Text | Free Full Text

140. Zhang X, Sejas DP, Qiu Y, et al.: Inflammatory ROS promote and cooperate with the Fanconi anemia mutation for hematopoietic senescence. J Cell Sci. 2007; 120(Pt 9): 1572-83.

PubMed Abstract | Publisher Full Text | Free Full Text

141. Sejas DP, Rani R, Qiu $Y$, et al.: Inflammatory reactive oxygen species-mediated hemopoietic suppression in Fancc-deficient mice. J Immunol. 2007; 178(8): 5277-87.

PubMed Abstract | Publisher Full Text | Free Full Text

142. Zhang X, Li J, Sejas DP, et al:: The Fanconi anemia proteins functionally interact with the protein kinase regulated by RNA (PKR). J Biol Chem. 2004; 279(42): 43910-9. PubMed Abstract | Publisher Full Text

143. F Karras GI, Yi S, Sahni N, et al.: HSP90 Shapes the Consequences of Human Genetic Variation. Cell. 2017; 168(5): 856-866.e12.

PubMed Abstract | Publisher Full Text | Free Full Text | F1000 Recommendation

144. Lin YR, Hung HC, Leu JH, et al.: The role of aldehyde dehydrogenase and hsp70 in suppression of white spot syndrome virus replication at high temperature. $J$ Virol. 2011; 85(7): 3517-25.

PubMed Abstract | Publisher Full Text | Free Full Text

145. Svahn J, Lanza T, Rathbun K, et al.: p38 Mitogen-activated protein kinase inhibition enhances in vitro erythropoiesis of Fanconi anemia, complementation group A-deficient bone marrow cells. Exp Hematol. 2015; 43(4): 295-9.

PubMed Abstract | Publisher Full Text

146. Brüne B, Dehne N, Grossmann N, et al.: Redox control of inflammation in macrophages. Antioxid Redox Signal. 2013; 19(6): 595-637. PubMed Abstract | Publisher Full Text | Free Full Text

147. Latorre $\mathrm{E}$, Mendoza $\mathrm{C}$, Layunta $\mathrm{E}$, et al:: TLR2, TLR3, and TLR4 activation specifically alters the oxidative status of intestinal epithelial cells. Cell Stress Chaperones. 2014; 19(2): 289-93.

PubMed Abstract | Publisher Full Text | Free Full Text

148. Lugrin J, Rosenblatt-Velin N, Parapanov R, et al:: The role of oxidative stress during inflammatory processes. Biol Chem. 2014; 395(2): 203-30. PubMed Abstract | Publisher Full Text

149. Salzano S, Checconi P, Hanschmann EM, et al.: Linkage of inflammation and oxidative stress via release of glutathionylated peroxiredoxin-2, which acts as a danger signal. Proc Natl Acad Sci U S A. 2014; 111(33): 12157-62. PubMed Abstract | Publisher Full Text | Free Full Text

150. F Pickrell AM, Youle RJ: The roles of PINK1, parkin, and mitochondrial fidelity in Parkinson's disease. Neuron. 2015; 85(2): 257-73.

PubMed Abstract | Publisher Full Text | Free Full Text | F1000 Recommendation

151. Yamashita T, Wu N, Kupfer G, et al.: Clinical variability of Fanconi anemia (type C) results from expression of an amino terminal truncated Fanconi anemia complementation group C polypeptide with partial activity. Blood. 1996; 87(10): 4424-32.

PubMed Abstract

152. F Ceccaldi R, Parmar K, Mouly E, et al.: Bone marrow failure in Fanconi anemia is triggered by an exacerbated p53/p21 DNA damage response that impairs hematopoietic stem and progenitor cells. Cell Stem Cell. 2012; 11(1): 36-49.

PubMed Abstract | Publisher Full Text | Free Full Text | F1000 Recommendation

153. Keijzers G, Bakula D, Scheibye-Knudsen M: Monogenic Diseases of DNA Repair. N Engl J Med. 2017; 377(19): 1868-76. PubMed Abstract | Publisher Full Tex

154. Mu Y, Gudey SK, Landström M: Non-Smad signaling pathways. Cell Tissue Res. 2012; 347(1): 11-20.

PubMed Abstract | Publisher Full Text

155. Sorrentino A, Thakur N, Grimsby S, et al.: The type ITGF-beta receptor engages TRAF6 to activate TAK1 in a receptor kinase-independent manner. Nat Cell Biol. 2008; 10(10): 1199-207.

PubMed Abstract | Publisher Full Text

156. F Challen GA, Boles NC, Chambers SM, et al:: Distinct hematopoietic stem cell subtypes are differentially regulated by TGF-beta1. Cell Stem Cell. 2010; 6(3): 265-78.

PubMed Abstract | Publisher Full Text | Free Full Text | F1000 Recommendation

157. F Chen W, Ten Dijke P: Immunoregulation by members of the TGF superfamily. Nat Rev Immunol. 2016; 16(12): 723-40. PubMed Abstract | Publisher Full Text | F1000 Recommendation

158. Hong JH, Lee GT, Lee JH, et al.: Effect of bone morphogenetic protein-6 on macrophages. Immunology. 2009; 128(1 Suppl): e442-50. PubMed Abstract | Publisher Full Text | Free Full Text

159. Kwon SJ, Lee GT, Lee JH, et al.: Bone morphogenetic protein-6 induces the expression of inducible nitric oxide synthase in macrophages. Immunology. 2009; 128(1 Suppl): e758-65.

PubMed Abstract | Publisher Full Text | Free Full Text

160. Wang N, Kim HG, Cotta CV, et al.: TGFbeta/BMP inhibits the bone marrow transformation capability of Hoxa9 by repressing its DNA-binding ability. EMBO J. 2006; 25(7): 1469-80.

PubMed Abstract | Publisher Full Text | Free Full Text

161. Nadler JJ, Braun RE: Fanconi anemia complementation group $C$ is required for proliferation of murine primordial germ cells. Genesis. 2000; 27(3): 117-23. PubMed Abstract | Publisher Full Text

162. Rodríguez-Marí A, Cañestro C, Bremiller RA, et al:: Sex reversal in zebrafish fanc mutants is caused by Tp53-mediated germ cell apoptosis. PLoS Genet. 2010; 6(7): e1001034.

PubMed Abstract | Publisher Full Text | Free Full Text

163. Gregory JJ Jr, Wagner JE, Verlander PC, et al.: Somatic mosaicism in Fancon anemia: evidence of genotypic reversion in lymphohematopoietic stem cells. Proc Natl Acad Sci U S A. 2001; 98(5): 2532-7. PubMed Abstract | Publisher Full Text | Free Full Text

164. Lo Ten Foe JR, Kwee ML, Rooimans MA, et al:: Somatic mosaicism in Fanconi anemia: molecular basis and clinical significance. Eur J Hum Genet. 1997; 5(3): $137-48$

PubMed Abstract

165. Waisfisz Q Morgan NV Savino M et al: Spontaneous functional correction of homozygous fanconi anaemia alleles reveals novel mechanistic basis for reverse mosaicism. Nat Genet. 1999; 22(4): 379-83. PubMed Abstract | Publisher Full Text

166. Li J, Sejas DP, Zhang X, et al: TNF-alpha induces leukemic clonal evolution ex vivo in Fanconi anemia group C murine stem cells. J Clin Invest. 2007; 117(11): 3283-95.

PubMed Abstract | Publisher Full Text | Free Full Text

167. Bagby GC, Meyers G: Bone marrow failure as a risk factor for clonal evolution: prospects for leukemia prevention. Hematology Am Soc Hematol Educ Program. 2007; 2007(1): 40-6.

PubMed Abstract | Publisher Full Text 


\section{Open Peer Review}

\section{Current Peer Review Status:}

\section{Editorial Note on the Review Process}

Faculty Reviews are review articles written by the prestigious Members of Faculty Opinions. The articles are commissioned and peer reviewed before publication to ensure that the final, published version is comprehensive and accessible. The reviewers who approved the final version are listed with their names and affiliations.

\section{The reviewers who approved this article are:}

\section{Version 1}

\section{Alex Lyakhovich}

Biomedical Research in Cancer Stem Cells, Vall d'Hebron Research Institute, Barcelona, Spain Competing Interests: No competing interests were disclosed.

2. Jakub Tolar Department of Pediatrics, University of Minnesota, Minneapolis, USA

Competing Interests: No competing interests were disclosed.

\section{Andrew Deans}

St. Vincent's Institute of Medical Research, Fitzroy, Victoria, Australia

Competing Interests: No competing interests were disclosed.

\section{Qishen Pang}

Division of Experimental Hematology and Cancer Biology, Cincinnati Children's Hospital Medical Center, Cincinnati, Ohio, USA

Competing Interests: Qishen Pang was a post-doctoral fellow in Grover Bagby's lab 20 years ago. 
The benefits of publishing with F1000Research:

- Your article is published within days, with no editorial bias

- You can publish traditional articles, null/negative results, case reports, data notes and more

- The peer review process is transparent and collaborative

- Your article is indexed in PubMed after passing peer review

- Dedicated customer support at every stage

For pre-submission enquiries, contact research@f1000.com 